\title{
Digital Storytelling in the Language Arts Classroom
}

\author{
Pınar Girmen ${ }^{1, *}$, Ümit Özkanal ${ }^{1}$, Gökhan Dayan² \\ ${ }^{1}$ Faculty of Education, Eskisehir Osmangazi University, Turkey \\ ${ }^{2}$ Seker Elementary School, Turkey
}

Copyright $\bigcirc 2019$ by authors, all rights reserved. Authors agree that this article remains permanently open access under the terms of the Creative Commons Attribution License 4.0 International License

\begin{abstract}
The aim of this study is to define the role of digital storytelling in improving writing skills. The study was designed as an action research. The study sample consisted of 22 fourth grade students in a public elementary school in Eskişehir, Turkey. Data were collected in 2017-2018 fall term through full participant observation, researcher's diaries, students' diaries, student digital processing products and video recordings. The learning materials were developed by the researchers based on the enriching texts and in-class action plans were designed based on the steps of digital storytelling. Data collected with researcher's diaries, observations, video recordings and documents were analyzed using content analysis. The results showed that digital story writing studies could be very effective in developing the writing skills of elementary school fourth grade students. Also, the digital story writing activities improved the students' computer literacy as well as their attitudes and motivation towards writing. Particularly, integration of technology in writing activities let the students see the course as a more modern, innovative and attractive course.
\end{abstract}

Keywords Writing Skills, Digital Storytelling, Language Arts, Elementary Education

\section{Introduction}

Writing, one of the four language teaching skills, is a relatively late developing skill with cognitive and physical processes [18]. Writing serves both as a way, which is a way to share our life experiences and to acquire regular thinking habit together with communication. Therefore, the development of writing skill also involves the development of thinking ability [32]. Developing writing skills help students express their feelings, opinions, imaginations, notions and impressions on anything by using the language based on grammatical rules [24].

The studies carried out in Turkey depict that most students have a weakness of writing skill. In fact, in terms of style, the most frequent problems are lack of punctuation, not starting a sentence with a capital letter and misspelling, words and syllables, and the problems in terms of content are lack of logical connections and content integrity among the sentences in a paragraph $[27,2,12]$. It may be stated that writing skill improves much slower than the other skills or does not improve enough because of high number of students in classes or some problems caused by teachers since it is a complex process, the feedback and correction processes during practice are not functional enough [21]. Numerous models and theories have been put forward regarding how writing skill may be gained and improved [19, 39, 31]. Although many studies have put forward that writing skill has been improved significantly based on the models and theories, how writing teaching and technology in the light of developing technology can be integrated is still a problem, which continues to be relevant. Digital storytelling is one of the steps, which may be a solution to the problems faced during the development of writing skill. Digital storytelling, which is a functional approach in integrating writing skill with technology, is also used in enriching learning environments. There are many different definitions of digital storytelling, but in general, they all revolve around the idea of combining the art of telling stories with a variety of digital multimedia.

Digital stories bring together some mixture of digital graphics, text, recorded audio narration, video and music to present information on a specific topic [28]. Digital storytelling approach has an important potential, which may be an educational model for the current era. Digital storytelling can also contribute in educating individuals who can analyze and interpret audio-visual outputs. Hence, it is an important, creative and functional approach for the new generation who will lead the future education [7] and can help improve writing skills of students. In terms of developing writing skills, it is important that writing skills course, which is a substantial skill in teaching languages, should be integrated with technology and the learning outcomes should be analyzed. The aim of this study is to define the role of digital storytelling in improving writing skills. 


\section{Methodology}

\subsection{Research Design}

The study was designed as an action research, one of the qualitative research methods, since it aims to define, describe the circumstances experienced during the application of digital storytelling in detail in the writing process of elementary school fourth grade students and offers a solution to the possible problems and deficiencies, which may be faced. Action research is described as a systematic research by which information on how school runs, how teaching is carried out and how students may learn better is obtained and it is carried out by teachers, principals, schools consultants or by other shareholders of teaching and learning environments [25].

\subsection{Participants}

The study sample consisted of 22 students, 10 male and 12 female, in a public elementary school in Eskişehir, Turkey. The participants were selected using the criterion sampling, a purposive sampling method. Criterion sampling involves examining all situations containing a variety of pre-determined criteria [37]. The inclusion criteria were that students attended a school that did not have a computer lab and were located in a low socio-cultural area, and that students did not have any idea on digital storytelling processes. The study sample included fourth grade students mainly because it was assumed that the students would have computer technology skills and writing skills at a certain level. The school in which the study was carried out was located in a low socio-economic area.

\subsection{Action Research Model}

The action research cycle was drawn on in this study. This model has its origins in the work of Kurt Lewin (1946). The model involves deciding on a particular focus for research, planning to implement an activity, series of activities, or other interventions, implementing these activities, observing the outcomes, reflecting on what has happened and then planning further activities if necessary [10]. Figure 1 depicts the action research cycle used in the study.

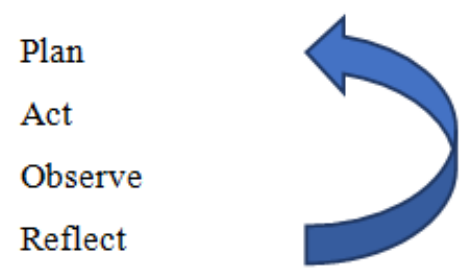

Figure 1. Action Research Model
Planning, a suitable teaching process was designed to have students write a digital story since the aim of the study was to improve students' writing skill with the help of digital storytelling

Act. Action theory was applied in order to check how the teaching and studies worked when the data were gathered systematically.

Observe. In this process, the relation between what was obtained and actions realized and the findings was determined.

Reflect. In the last phase of action research, analysis, planning and reporting actions were carried out. The date gathered were analyzed and the results obtained were used in the revision of action plans.

\subsection{Data Collection and Analysis}

Data were collected in 2017-2018 fall term in a ten -week process by the researcher through full participant observation, researcher's diaries, students' diaries, student digital processing products and video recordings. The learning materials were developed by the researchers based on the enriching texts and in-class action plans were designed based on the steps of digital storytelling. The action plans prepared were presented to the validity committee and field experts and necessary corrections were done based on the feedbacks.

Data collected with researcher's diaries, observations, video recordings and documents were analyzed using content analysis. Just before the implementation of the content analysis, the notes taken by the researchers during the observation and students' diaries were examined in detail and transcribed on computer using a word processor.

The qualitative data in the video recordings were texted into the computer and they were formed as textual data proper for the analysis. Digital outputs by the students and screen shots of all acts were gathered by the researcher and turned into analysis data. The data texts in the computer on observation and diaries were divided into meaningful parts, named by the researchers and a code list was formed.

During the coding process, the conceptual frame of the study was taken into consideration. After bringing all the codes together, the common directions among the codes were formed. The data obtained were categorized and the themes forming the main lines of the researchers' findings were reached.

The available coding list and themes were finalized based on the opinions of the experts.

The quotations were given directly with initials like video recording (V. R.), researcher's diary (R. D.) and students' diary (S. D.). The themes, sub-themes and codes of the study are depicted in Table 1. 
Table 1. Themes, Sub Themes and Codes

\begin{tabular}{ccc}
\hline THEMES & SUB-THEMES & CODES \\
\hline Reflections of Writing Process & Writing Skill & $\begin{array}{c}\text { Spelling and Punctuation } \\
\text { Digital Story Elements } \\
\text { Creating Text } \\
\text { Preparatory Studies }\end{array}$ \\
\cline { 2 - 3 } Reflections on Learning Environment & Use of Computer \\
& Technologies & $\begin{array}{c}\text { Keyboard Knowledge } \\
\text { Searching in the Net }\end{array}$ \\
& Learning mass & $\begin{array}{c}\text { Cooperation } \\
\text { Peer Learning }\end{array}$ \\
\cline { 2 - 3 } & Reflections on the \\
& Course & Attitude \\
& Motivation \\
Self Confidence
\end{tabular}

\subsection{Validity and Reliability}

The conclusiveness (i.e., accuracy, validity, reliability) in qualitative studies means the observation and transfer of the data as they are or as neutral as possible [22]. On the other hand, the repeatability (i.e., reliability, transferability, approvability) states that similar situations may occur [37]. The necessary permissions from the institution, students, teachers and parents were obtained in the study. The opinions of the experts and validity committee on action plans and the appropriateness of the enriching texts were applied and corrections were made accordingly.

At the same time, the variety of researcher was tried to get with the study of the data by the researchers separately. The data were presented to the validity committee that met regularly and their opinions on the study were obtained.

Doing so, the reliability of the study was tried to get. On the transferability of the study, detailed descriptions and direct citations were included in the presentation of the findings. Therefore, it can be stated that the results of the study can be applied in classes having the same conditions and those having better conditions.

\subsection{Application of the Research}

In this part, the process of the research from the start until the end is defined. The codes of practice showing the stages of the research, the action plan, are shown in Figure 2 in detail.

Deciding on a Web-based Video Formation Software. The web-based video formation software "GoAnimate" including lots of scenes and cartoon characters was chosen for the research.

Deciding on the Activities for Digital Story Making. The strategy to decide on which activities to use, was to follow the way from simple to complex ones. For this purpose, activities for making dialogues, making descriptions, making advertisements, informative texts and stories were included.

Supporting the Technological Background of the School. The inadequate number of computers was increased for being able to perform the digital narrative activities smoothly. A digital camera and a tripod were placed into the practice classroom.

The Codes of Practice for the Research Process

Deciding on a Web -based Video

Formation Software

Deciding on the Activities for Digital

Story Making

Supporting the Technological

Background of the School

Introducing the Computer Software to

Students

\section{Deciding on the Warm-up Activities}

\section{Digital Narration Process}

\section{Sharing}

Figure 2. The Codes of Practice for the Research Process

Introducing the Computer Software to Students. Before the start of the process, the researcher had come together with the group of 22 students in classroom environment and informed them about digital narration. In addition to this, a presentation was prepared by the researcher to present the features and the use of the web site for an adequate application of it.

By this, students were equipped with the necessary information for the use of the web site.

Deciding on the Warm-up Activities. The identification of the items as supportive content presented by the researchers was actualized before digital stories were made 
up. Within this framework, the visuals, descriptive texts, coloring practices, sample dialogues, informative texts and cartoons to be used during teaching-learning process were determined.

Digital Narration Process. Digital narration steps consisted of forming the scenes, adding the written work, giving effects, and arrangement and correction. Through each phase, the researcher watched, guided and observed the students and helped the ones in need during the production of digital output.

Sharing. The digital stories formed by the students were shared by the target group at this phase. Before starting forming their digital stories, the students were informed about who they were going to form their stories for. The target group had been defined before forming the digital stories.

\subsection{Working Calendar of the Study}

The activities carried out are depicted based on week and class hour in Table 2.

\section{Findings}

In the presentation of the findings and comments, the themes found out by the content analysis were considered and the citations which best explain the theme were included. Intended for the purpose of the research, the data gathered via video recordings, student and researcher, student products and voice recordings were analyzed and it was aimed to form a profound frame for the use of digital narration study in teaching writing.

Table 2. Working Calendar of the Study

\begin{tabular}{|c|c|c|c|}
\hline Week & Time & $\begin{array}{c}\text { Briefing/ } \\
\text { Created Texts }\end{array}$ & $\begin{array}{c}\text { Practice Notes/ } \\
\text { Enriching Activities }\end{array}$ \\
\hline 1 & $160 \mathrm{~m}$ & $\begin{array}{l}\text { Technical Briefing on Digital } \\
\text { Story telling }\end{array}$ & Introduction of the website. \\
\hline 2 & $160 \mathrm{~m}$ & Introduction of Digital Storytelling Phases & $\begin{array}{l}\text { Creating scenes, adding script, } \\
\text { effects and music }\end{array}$ \\
\hline \multirow[t]{2}{*}{3} & $160 \mathrm{~m}$ & Creating Dialogue & $\begin{array}{c}\text { Puppet videos were watched as } \\
\text { enriching texts and texts with dialogues } \\
\text { were presented }\end{array}$ \\
\hline & $80 \mathrm{~m}$ & Output Presentation & $\begin{array}{c}\text { Outputs formed by pairs were } \\
\text { presented in class } \\
\end{array}$ \\
\hline \multirow{2}{*}{4} & $160 \mathrm{~m}$ & $\begin{array}{l}\text { Creating Person/ } \\
\text { Object Imagery }\end{array}$ & $\begin{array}{l}\text { Pausing the tales listened in class } \\
\text { a discussion setting was created }\end{array}$ \\
\hline & $80 \mathrm{~m}$ & Output Presentation & $\begin{array}{c}\text { Individual Outputs were presented } \\
\text { in class }\end{array}$ \\
\hline 5 & $120 \mathrm{~m}$ & $\begin{array}{c}\text { Creating } \\
\text { Advertisement }\end{array}$ & Advertisement videos were watched. \\
\hline 6 & $40 \mathrm{~m}$ & Output Presentation & $\begin{array}{l}\text { Advertisements on school introduction } \\
\text { were shared with other } 4^{\text {th }} \text { class students }\end{array}$ \\
\hline 7 & $160 \mathrm{~m}$ & Creating Information Texts & $\begin{array}{l}\text { A brochure about the city's cultural and } \\
\text { tourist attraction places was shared and } \\
\text { a city introduction video was watched. }\end{array}$ \\
\hline 8 & $120 \mathrm{~m}$ & Output Presentation & $\begin{array}{l}\text { Outputs prepared was presented to } \\
\text { first grade students who were } \\
\text { determined as target group } \\
\end{array}$ \\
\hline 9 & $200 \mathrm{~m}$ & Creating Story & $\begin{array}{l}\text { An animated video was watched } \\
\text { as enriching text }\end{array}$ \\
\hline 10 & $160 \mathrm{~m}$ & Output Presentation & $\begin{array}{l}\text { Outputs were presented to the students' } \\
\text { families as target group }\end{array}$ \\
\hline
\end{tabular}




\section{The Reflections on the Writing Process}

When the digital stories of the students were studied, although the first drafts were full of mistakes, it was observed that this problem decreased gradually. Even though almost no punctuation was used in the first drafts, some progress relating to the matter was made onwards the second drafts. When observed in terms of punctuation, it was analyzed that all students used correct punctuation in their final work. This could be related with the immediate feedback of the researcher, the group work of the students and their high motivation on digital story formation. When the first drafts were studied in terms of spelling rules, it is observed that there were missing or wrong letters in words, some incorrectly adjoined conjunction and question word mistakes, and also no space was left between words. Some examples of the first draft mistakes are as follows:

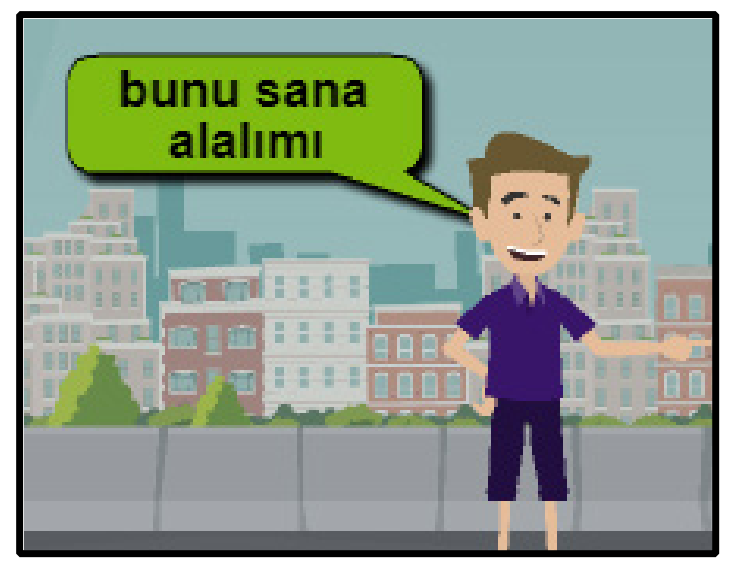

(Shall we buy this for you?)

Note. "https:/goanimate.com/" [20]

Correct Sentence: "Bunu sana alalım mi?"

Figure 3. Missing letter

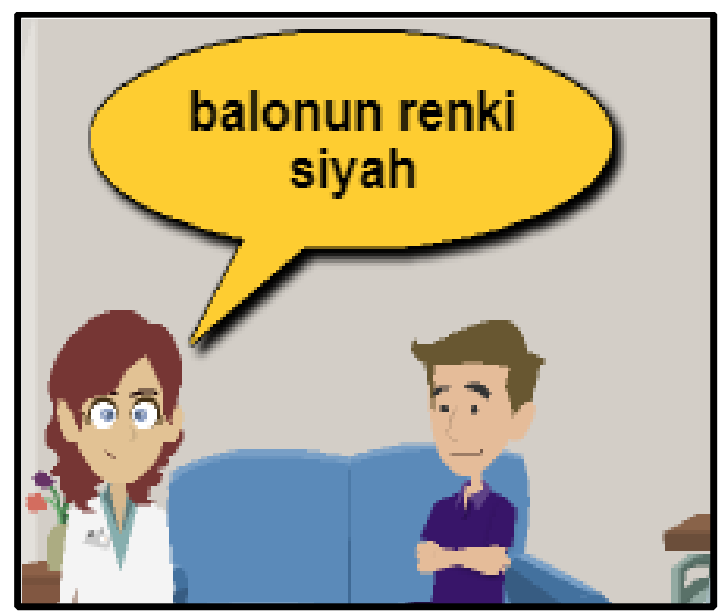

(The color of the balloon is black)

Note. "https://goanimate.com/" [20]

Correct Sentence: "Balonun rengi siyah."

Figure 4. Wrong letter

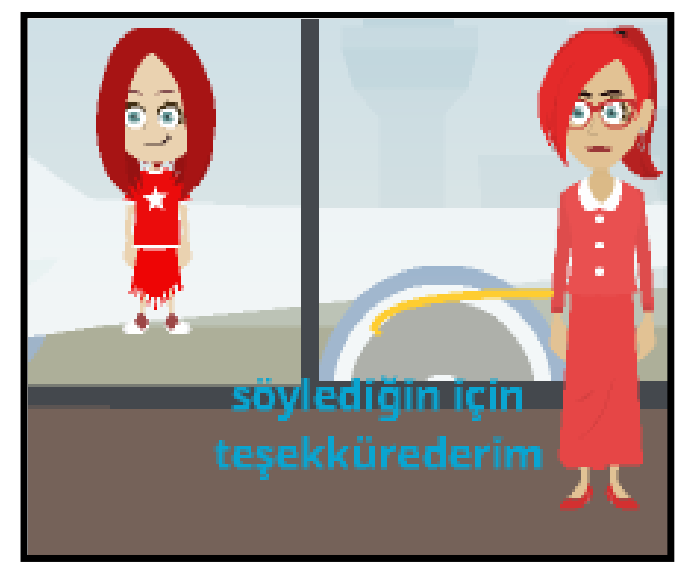

(Thank you for saying it)

Note. "https://goanimate.com/" [20]

Correct Sentence: "Söylediğin için teşekkür ederim."

Figure 5. Leaving no space between words

It was found that the spelling mistakes decreased during the process of the student outputs. The most significant reason for this improvement was most probably the subsidiary role of the computer. This aspect of the computer software provided immediate self-correction opportunity to the student. The feedback from the researcher was also one of the other reasons for the decrease. It was observed that there were almost no mistakes as the process progressed. Some examples of the improvement in this respect are as follows:

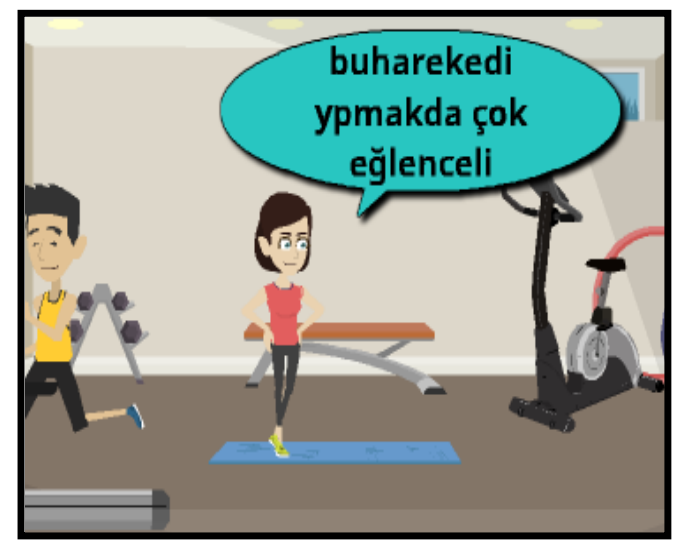

(It is very enjoyable to do this movement)

Note. "https://goanimate.com/" [20]

Correct Sentence: "Bu hareketi yapmak da çok eğlenceli."

Figure 6. Mistakes in the first digital output

Table 3. Types of mistakes in the first digital output

Not capitalizing the first letter of the sentence

Writing the words without leaving space between words

Adjacent use of conjunctions

Not punctuating

Missing letter

Wrong letter use 


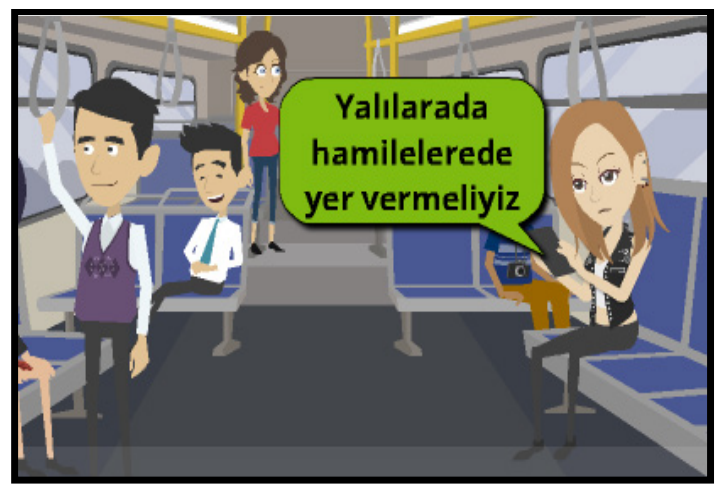

(We should give up our seats to the elderly and pregnant) Note. "https://goanimate.com/" [20]

Correct Sentence: "Yaşlılara da, hamilelere de yer vermeliyiz."

Figure 7. Mistakes in the second digital output

Table 4. Types of mistakes in the second digital output

Missing letter

Adjacent use of conjunctions

Not punctuating

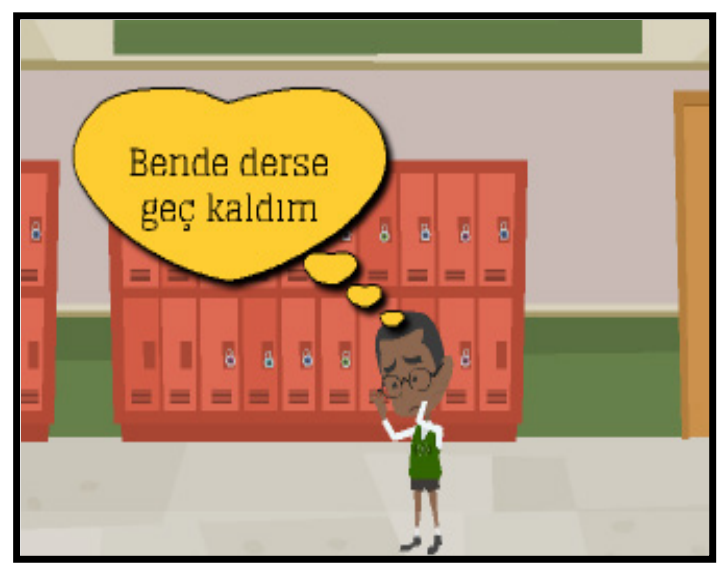

Note. "https://goanimate.com/" [20]

(I am late for the class too)

Correct Sentence: "Ben de derse geç kaldım."

Figure 8. Mistakes in the third digital output

Table 5. Types of mistakes in the third digital output

Adjacent use of conjunctions

Not punctuating

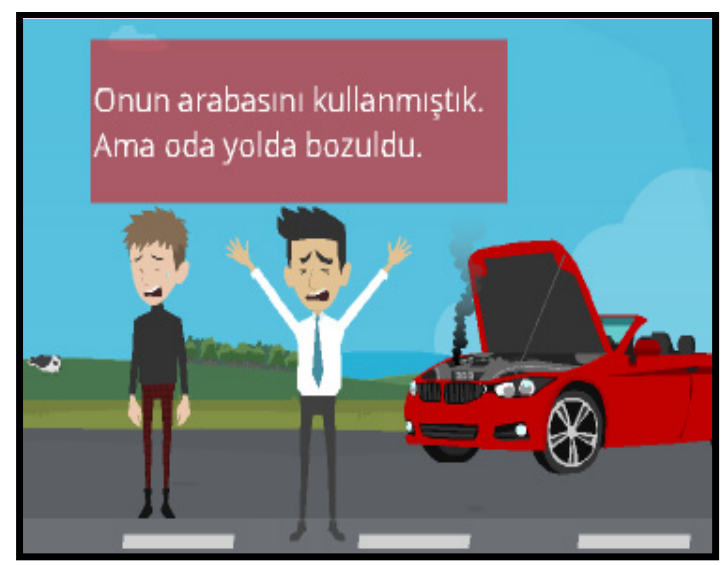

Note. "https://goanimate.com/" [20]

(We drove his car but it broke down on the way)

Correct Sentence: "Onun arabasını kullanmıştık. Ama o da yolda bozuldu."

Figure 9. Mistakes in the fourth digital output

Table 6. Types of mistakes in the fourth digital output

Adjacent use of conjunctions

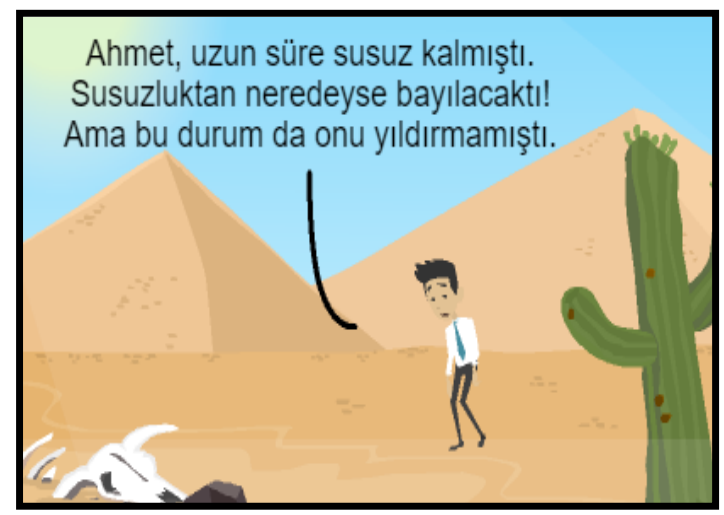

(Ahmet was without water for a long time. He was about to pass out. However, this did not discourage him)

Note. "https://goanimate.com/" [20]

Figure 10. Error-free sentence in the fifth digital output

In this respect some statements from student are as follows:

"At the beginning, my sentences seemed correct to me. I later on realized that I had some mistaken parts in my work."(S.D.4, 05.10.2017). 
"As long as the activities proceeded, the change in my writing distinguished itself. I used to make too many mistakes on conjunctions. I sometimes didn't punctuate full stops. Then I started to correct myself."(S.D.6, 10.10.2017).

"Our teacher used to tell us about our mistakes. S/he used to correct us at once. I took her corrections into consideration and improved my writing."(S.D.7, 12.10.2017).

"The computer automatically underlined the misspelled words. I usually noticed my mistake on the screen. Our teacher also pointed out my mistakes immediately." (S.D.1, 13.10.2017).

When the outputs investigated in terms of using of the digital story elements, it was seen that most students could not add any audial or visual effects to their digital stories. The outputs in the beginning came out without music and as short scenes. It can be stated that with the third digital output students started to add music together with audial and visual effects. Similarly, while preparing the third digital output, the students showed the ability of choosing correct character for the theme and proper facial expressions.

The students acquired the ability of adding movement to the characters in the third digital output. The diary of the researcher is as follows:

"The number of scenes has increased when compared with the first output. This also applies with the video duration of the scenes. Each scene in digital output takes ten seconds. They have learnt how to increase duration of the scenes and arranging them in accordance with the length of the speeches. They can use the duration arrangement part effectively at the sub-section of the software. "(R.D. 11, 16.10.2017).

"The facial expressions of the characters are quite clear based on the story. The facial expressions of the characters change accordingly. They, now, can add movement easily that they have not been able to do at first. The more they have used them, the happier they have become. They are especially happy when flying the character" (R.D. 14, 23.10.2017).

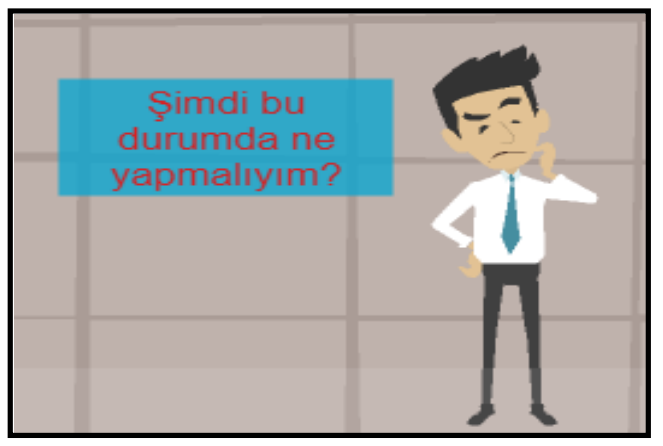

(What should I do now in this situation?)

Note. "https://goanimate.com/" [20]

Figure 11. The expression of confused

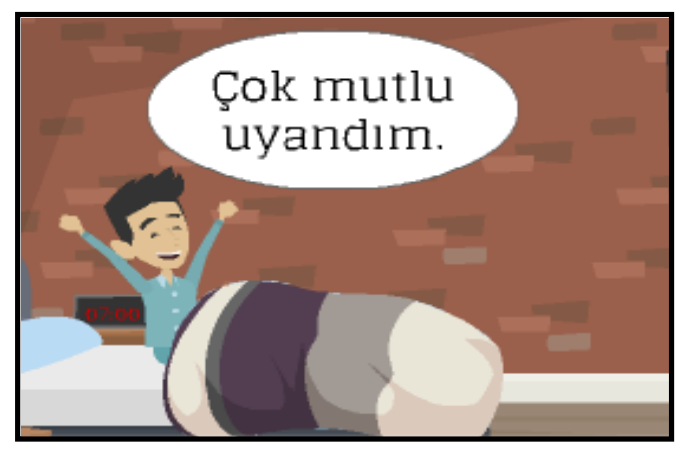

(I have woken up very happy)

Note. "https://goanimate.com/” [20]

Figure 12. The expression of happiness

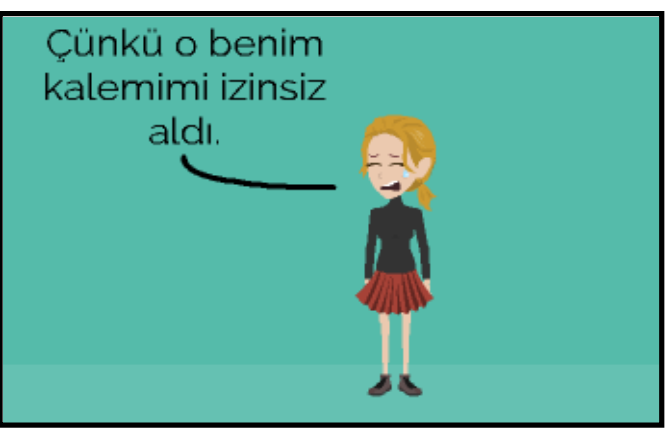

(Because he got my pen without my permission)

Note. "https://goanimate.com/" [20]

Figure 13. The expression of tearful

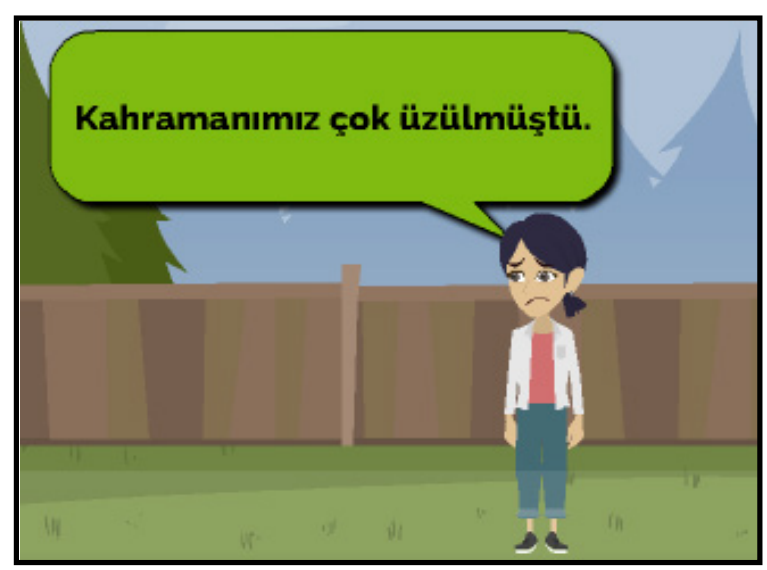

(Our character was very worried)

Note. "https://goanimate.com/" [20]

Figure 14. The expression of sorry

When the students' digital outputs studied in terms of forming stories, major differences between the first and last outputs were observed. While their outputs were of short sentences, when they proceeded it was seen that they started to use conjunctions. Not clear acts, low number of character and short sentences were replaced with detailed expressions.

Similarly, the students put forward their messages in their last two outputs. The main reason for this change 
might be the pre-preparing texts presented to the students. That in their outputs, they had some inspirations from the texts they listened to or watched might be the reason of this development.

When the students' outputs were studied in terms of pre-preparing texts, it may be stated that the students were affected a lot what they listened to and watched. It was seen some concrete tracts of pre-preparing texts in the outputs. The discussions done and the points the researcher put forward after watching and listening activities were also reflected in the outputs. This can be seen in the video recording as follows:

Researcher: I want you to take these into consideration.

Student 1: Teacher, got it! Just like the cartoon we have watched. Since it is rainy, they should take what you have shown (V.R. 11, 17.10.2017).

Researcher: Do you like the video?

Students: Yes teacher.

Researcher: Well, has this video created anything in your mind? Where do you think it can be used?

Student 8: It is suitable for my scene for example. I can use the animals here when the duck has run away from the hunter (V.R. 13, 19.10.2017).

As seen above, it can be stated that the pre-preparing texts affected and revived the students.

When the digital story process of the students studied, it was found out that they lacked of knowledge in terms of computer literacy. They were observed to be lacking knowledge of keyboard and searching ability on the Internet. It was witnessed that in terms of keyboard knowledge, they had difficulty in using caps lock, backspace, space bar and enter keys. The reason of the problem might be that they used more tablets and smart phones than computers in their daily lives. During the study, it was observed that they developed themselves in computer literacy. The reflections of students are as follows:

"I have learnt to use caps lock and put apostrophe in the key board. Then I have learnt where to find question mark, coma and full stop. I have also learnt the places of the letters in the keyboard. I have experienced the Num Lock key twice.

I have learnt that when I press the key, number get active", (S.D. 12, 17.10.2017).

"I have learnt to write in capitals and lower case letters. I have just learnt caps Lock. When pressed Ctrl, we can get capital letter. When pressed the key enter, the sentence comes under. When pressed the key having a line over, what you write is deleted. I have just learnt them all” (S.D. 10, 25.10.2017).

When the students' ability of searching on the Internet studied, it was observed that at the beginning the students had difficulty to get visuals and do search in the net for their digital stories. This is reflected in the diary of the researchers as follows:
"The visuals they want to implement in their studies are not always available in the software they use. I direct the students who want to use different visuals to do search in the "Google". Those not having enough ability to use the technology are in real difficulty in finding and saving the proper visual. I am teaching them how to get the proper visual by using some key words and save to the computer so that they can use it later" (R.D.21, 03.11.2017).

It was seen that when digital story making process proceeded, the students were able to implement proper visuals they got from the Internet. In the last digital story, the captions on visuals that they received in the net are below.

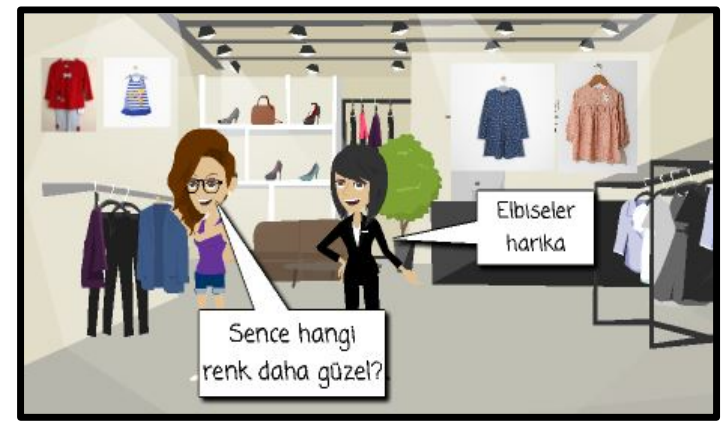

(Which color is better for you?)

(The dresses are great.)

Note. "https://goanimate.com/" [20]

Figure 15. Dressed downloaded from Google Visuals

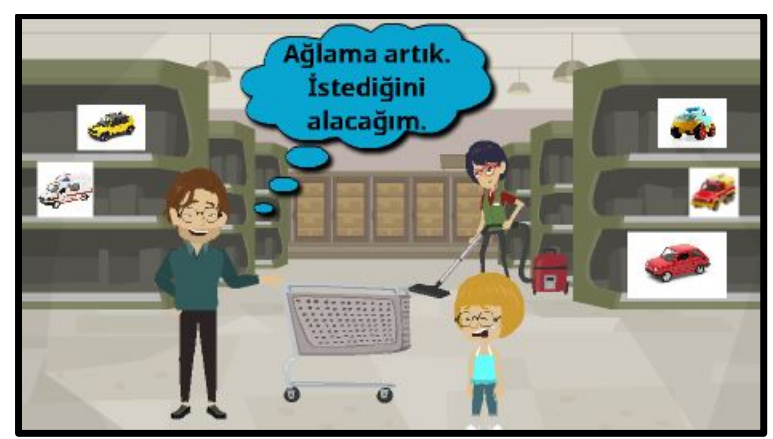

(Do not cry anymore, I will buy what you want)

Note. "https://goanimate.com/" [20]

Figure 16. Toys downloaded from Google Visuals

\section{Reflections on Learning Environment}

The students put forward their digital stories in pairs. It was witnessed that the conflict between them decreased in time. It was observed that they learnt a lot on the use of computer and/ or software and shared a lot of information as to the process. It was also seen that the students always worked in cooperation and supported each other in determining the characters, places, plots, time and any elements as to what they did. The video recordings are as follows: 
Researcher: Have you downloaded your digital story? Student 3: Yes, teacher. We have finished our work. He has used the keyboard and I have moved the mouse. Now we are checking it all before downloading.

Student 7: We may make some changes on this scene (pointing it out with hand). What do you think?

Researcher: It seems nice. I like the flag especially. If you really like, you may change it.

Student 7: Teacher, we have chosen that flag together among the other flags in Google visuals.

Student 3: Yes teacher, we have chosen the best one. Then we added an atomic bomb effect to the flag and the script was written in capital letters.

Student 7: Teacher, I have taught him how to write in capital letters. The other group has liked that effect too but they have not been able to find where to get it. We have shown them how to.

Student 3: I have also taught you how to save it, remember the scene with nutrition?

Researcher: Very good, you share your knowledge. If you are not doing any changes, download your digital story now. (V.R.22, 06.11.2017).

It was found out that the students' motivation and attitude towards the course had an increasing trend in the study of digital story making. It was observed that at first the students' anxiety level when preparing the digital stories was high but they had curiosity and a will to write. The will to write and their excitement of the students can be depicted as follows:

Researcher: The lesson is about to be over. I want to learn what you think about what we have been doing so far.

Student 16: Teacher, I have not noticed how fast the class has gone on, as if we have just started.

Researcher: If you raise your hands, I can see what everybody thinks. Yes, you.

Student 20: During my first digital story I have felt a little bit stressed and I have had the feeling of being unsuccessful. That's first, then I have overcome my stress.

Student 8: Teacher, I have been wondering what kind of outcome I might have had. It has been so nice to do the activities here than the book only.

Student 14: At first I have been afraid to make mistakes. I have been so scared to make something wrong or delete what I have done. I have been astonished in giving effect to the texts. This is much more fun even if I have had some difficulties.

Student 6: What I wanted to do a lot is to move the character and also add sound. I have been so happy to hear my own voice.

Student 2: What I liked a lot is my own voice in the story. Other cartoons are voiced by others but here I do it with my own voice since this is mine. Very nice to hear your own voice in the video (V.R.25, 13.11.2017).
During the digital story making process, the anxiety the students had in forming a digital story was replaced by self-confidence. This is how reflected in the researcher's diary.

"I observe that my students work much harder after they have learnt how to use the software. The fear of not being able to do anything seen at first has now left its place to the happiness of doing something good. Those who were afraid of doing anything at the computer now can say that "no problem, I can do it". We have much better results in each trial of voiceover (R.D.27, 15.11.2017).

When the students created and presented their outputs, they saw that they did it well and started to write with a high self-confidence. At the same time, that their computer literacy developed in time and how to use the software supported their self-confidence. The reflection of students is as follows:

"I did not use to know how to do search on the net but I now trust myself more than ever on it. My self-confidence has arisen (S.D.17, 10.11.2017).

I have done the search willingly and in enjoyment. In the past, I used to search on the books or dictionaries but now I have learnt that I can do search on the net (S.D.11, 14.11.2017).

I did not know about Google visuals before. First I downloaded proper visuals from Google visuals for my story, then I put them as objects in the software. I can do it easily now (S.D.20, 17.11.2017).

The digital story writing, which is totally different from the usual activities, gave the students the opportunity of attendance to the course willingly and has eradicated monotonous class atmosphere. This caused the development of a positive attitude towards the course and increased the motivation of the students.

That the digital stories were shared with target audience developed in the students the feeling what they did was functional.

The students stated that writing activities were not enjoyable and boring before. The statements on this are as follows:

Turkish courses have not been enjoyable. They have been very boring. We have been writing too much (S.D.14, 24.11.2017).

\section{Discussion and Conclusions}

The results revealed that digital storytelling studies might be very effective in developing the writing skill of elementary school fourth grade students. In addition, the digital story writing studies supported the students' computer literacy and improved their attitudes and motivation towards writing. A lot of studies on the issue stated that digital storytelling improved the motivation of 
students on writing [34, 33, 26, 13, 16, 36]; and developed their technological literacy $[11,28,6]$. These activities had a very important role in affecting students' attitude and motivation towards the course with the integration of writing with the technology and making the course a new and attractive one by taking the scope of the course from classical route to the modern one. According to the study of Sadık [29] digital storytelling provided an authentic way to help students learn how to use technology effectively in their learning, particularly if provided with appropriate digital resources and usable editing tools to further motivate them into creating quality stories. To some other research findings, digital story was found to contribute to creativity, innovation, collaborative learning, and student motivation in reading and writing $[3,4,15,30]$. In another study by Dogan and Robin [14], the elementary, middle, and high school teachers who attended a digital storytelling workshop reported positive effects of digital storytelling on student performance, 21st century skills, motivation and engagement levels.

That preparative texts were used in the studies of writing and creating a variety of preparative texts enrich the writing content of students and gave them a point of view on what they did. The preparative texts were produced by different text makers enriched the learning environment and gave students alternatives.

The process of digital storytelling supported the writing skills in terms of application of spelling and punctuation rules, text forming, making connections among paragraphs, and forming introduction, body and conclusion. In a similar study, it was put forward by Xin [35] that it improved the students' writing skill in terms of total number of words, number of whole sentences and using correct word. That they did digital story telling studies in small groups provided the students work in cooperation and peer learning. Similarly, Behmer [5] stated that digital storytelling process, with the use of communication and technological gadgets, enabled students to work collaboratively with their peers and study on different issues thinking critically.

As stressed by Yüksel and others to support the results of the study [38], digital story telling activities were generally designed and run as small group activities and they had a function to support and increase in class cooperation. This also created an atmosphere of communication among the students, expression of their opinions and share of their studies with peers $[1,17]$. It was found out that digital storytelling studies supported students' self-confidence on writing. Those students observed their own improvement in writing concretely enhanced their motivation and class participation. According to Bumgarner and Campbell [8,9], digital storytelling activities increased students' class participation and writing self-perception. Moreover, it was stated that digital stories enhanced students' own style for self-expression and self-reflection [23].

\section{Suggestions}

Since digital storytelling is a new educational technology tool, teachers should be informed on the issue and some application samples should be shared with them to use in the classroom situation. Pre-service and in-service implementation of new technology tools into instruction should be added to the curriculum.

The technological literacy level of the students should be determined before starting digital story telling studies. The opportunities of the Internet should be utilized so that the output of the students can be shared with the mass out of the classroom.

Technological integration with writing should be acquired and this should be associated with the students' daily lives. Teachers should be encouraged to use digital storytelling in their writing courses.

\section{REFERENCES}

[1] Abiola, L.L. (2014). The effect of digital storytelling on kindergarten pupils' achievement in moral instruction in basic schools in Oyo State. IOSR Journal of Research \& Method in Education, 4(5), 26-34.

[2] Alkan, Z. N. (2007). İlköğretim beşinci sınıf öğrencilerinin yazılı anlatım hataları. Yayınlanmamış yüksek lisans tezi. Eskişehir Osmangazi Üniversitesi Sosyal Bilimler Enstitüsü.

[3] Ballast, K., Stephens, L., Radcliffe, R. (2008). The effects of digital storytelling on sixth grade students' writing and their attitudes about writing. In K. McFerrin et al. (Eds.), Proceedings of Society for Information Technology and Teacher Education International Conference (pp. 875-879). Chesapeake, VA: AACE.

[4] Banaszewski, M. T. (2005). Digital storytelling: Supporting digital literacy in grades $4-12$. Master's thesis, Georgia Institute of Technology. Retrieved from

http://techszewski.blogs.com/techszewski/files/TBanaszew ski_DS thesis.pdf

[5] Behmer, S. (2005). Digital Storytelling: Examining the process with middle school students, Ames, IA: Iowa State University.

[6] Behmer, S., Schmidt, D., Schmidt, J. (2006). Everyone has a story to tell: Examining digital storytelling in the classroom. In C. Crawford et al. (Eds.), Proceedings of Society for Information Technology and Teacher Education International Conference 2006 (pp. 655-662). Chesapeake, VA: Association for the Advancement of Computers in Education.

[7] Bozdoğan, D. (2012). Content analysis of elt students' digital stories for young learners. Novitas-ROYAL (Research on Youth and Language), 6(2), 126-136.

[8] Bumgarner, B. L. (2012). Digital storytelling in writing: A case study of student teacher attitudes toward teaching with technology. Unpublished doctoral dissertation. The Faculty 
of the Graduate School University of Missouri, Jesse Hall.

[9] Campbell, T., (2012). Digital storytelling in an elementary classroom: Going beyond entertainment. Procedia - Social and Behavioral Sciences, 69, 385-393.

[10] Costello, P. J. M. (2003). Action Research. London: Continuum.

[11] Czarnecki, K. (2009). Digital storytelling in practice: Storytelling in context. Library Technology Reports, 45(7), 5-8.

[12] Demir, K. (2000). Yazılı anlatım becerileri bakımından köy ve kent beşinci sınıf öğrencilerinin durumu. Yayınlanmamış yüksek lisans tezi. Çanakkale On Sekiz Mart Üniversitesi Sosyal Bilimler Enstitüsü.

[13] Demirer, V. (2013). İlköğretim e-öyküleme kullanımı ve etkileri. Doktora tezi. Necmettin Erbakan Üniversitesi Eğitim Bilimleri Enstitüsü.

[14] Dogan, B., Robin, B. (2008). Implementation of digital storytelling in the classroom by teachers trained in a digital storytelling workshop. In K. McFerrin et al. (Eds.), Proceedings of Society for Information Technology and Teacher Education International Conference (pp. 902-907). Chesapeake, VA: AACE. Retrieved from http://www.editlib.org/p/27287.

[15] Dollar, K.Y., Tolu, T. A. (2015). My first digital story: a case study with 5 th grade Turkish English language learners. International Association of Research in Foreign Language Education and Applied Linguistics ELT Research Journal, 4(3), 172-185

[16] Foley, M. L. (2013). Digital storytelling in primary-grade classrooms. Unpublished doctoral dissertation. Arizona State University, Pheonix.

[17] Gözen, G., Cırık, İ. (2017). Impact of Digital Storytelling on Social-Emotional Behaviours of Preschool Children. Elementary Education Online, 16(4): 1882-1896

[18] Güneş, F. (2013). Türkçe Öğretimi Yaklaşımlar ve Modeller. Ankara: Pegem Akademi.

[19] Harris, K. R., Graham, S. (1996). Making the writing process work: Strategies for composing and self-regulation. Cambridge, MA: Brookline.

[20] https://goanimate.com/

[21] Karatay, H. (2011). 4+1 Planlı Yazma ve Değerlendirme Modelinin Öğretmen Adaylarının Yazılı Anlatım Tutumlarını ve Yazma Becerilerini Geliştirmeye Etkisi. Turkish Studies, Volume 6 (3), 1029-1047.

[22] Kirk, J., Miller, L. M. (1986). Reliability and Validty in Qualitative Research. Sage Publications.

[23] Lee, H-C. (2014). Using an arts-integrated multimodal approach to promote English learning: A case study of two Taiwanese junior college students. English Teaching: Practice and Critique, 13(2), 55-75.

[24] MEB. (2015). İlköğretim Türkçe Dersi Öğretim Programı ve Kılavuzu (1-8. Sınıflar). Ankara: Milli Eğitim Bakanlığı Yayınları.

[25] Mills, G.E. (2003). Action Research: A guide for the teacher researcher. New Jersey: Prentice-Hall

[26] Norman, A. (2011). Digital storytelling in second language learning: A qualitative study on students' reflections on potentials for learning. Unpublished doctoral dissertation. Norwegian University of Science and Technology.

[27] Önder, H. (2009). Anlatma Teknikleri (Konuşma ve Yazma). İzmir: Orkun Kitabevi.

[28] Robin, B. (2006). The educational uses of digital storytelling. Technology and teacher education annual, 1, 709.

[29] Sadik, A. (2008). Digital storytelling: a meaningful technology-integrated approach for engaged student learning Educational Technology, Research and Development. New York: Vol. 56, Iss. 4, 487-506.

[30] Salpeter, J. (2005). Telling tales with technology, Technology \& Learning 25 no 7.

[31] Tompkins, G.E. (2008). Teaching writing: Balancing process and product. Upper Saddle River, NJ: Pearson.

[32] Ünalan, Ş. (2006). Türkçe Öğretimi. Ankara: Nobel Yayın Dağıtım.

[33] Vasudevan, L., Schultz, K., Bateman, J. (2010). Rethinking composing in a digital age: Authoring literate identities through multimodal storytelling. Written Communication, 27(4), 442-468.

[34] Wu, W.C., Yang, Y. T. (2008). The impact of digital storytelling and of thinking styles on elementary school students' creative thinking, learning motivation, and academic achievement. K. McFerrin v.d. (Ed.), Proceedings of Society for Information Technology \& Teacher Education International Conference pp. 975-981.

[35] Xin, J. (2013). Using digital stories in writing instruction for secondary students with disabilities. International Conference on Educational Research and Sports Education (ERSE 2013). Atlantis.

[36] Yamaç, A. (2015). İlkokul üçüncü sınıf öğrencilerinin yazma becerilerinin geișiminde dijital hikayelerin etkisi. Yayınlanmamış doktora tezi. Gazi Üniversitesi Eğitim Bilimleri Enstitüsü.

[37] Yıldırım, A., Şimşek, H. (2013). Sosyal Bilimlerde Nitel Araştırma Yöntemleri. Ankara: Seçkin Yayıncılık.

[38] Yüksel, P., Robin, B. R., McNeil, S. (2011). Educational uses of digital storytelling around the world. In Proceedings of Society for Information Technology and Teacher Education International Conference, 1(1), 1264-1271.

[39] Zimmerman, B., Risemberg, R. (1997). Becoming a self-regulated writer: A social cognitive perspective. Contemporary Educational Psychology, 22, 73-101. 